\title{
Nipple Retractor to Correct Inverted Nipples
}

\author{
Xiao Long Ru Zhao \\ Department of Plastic and Reconstructive Surgery, Peking Union Medical College Hospital, Beijing, China
}

Keywords

Inverted nipple $\cdot$ Surgery $\cdot$ Nipple retractor

\section{Summary}

Background: Inverted nipples are a common problem and a challenging clinical condition to repair. Multiple methods have been reported to correct inverted nipples, most of which will destroy breastfeeding function. Patients and Methods: We have designed a simple nipple retractor to correct inverted nipples. A total of 53 patients with 95 inverted nipples underwent an operation in which the nipples were retracted into a normal position and fixated with the nipple retractor and wires under local anesthesia. Nipple retractors were to be worn for 6 months. Postoperatively, the patients were invited to follow-up on the 1st day, the 7th day, after 1 month, 3 months and 6 months, and yearly thereafter. Wire adjustments were performed as needed. Mean follow-up was 11.9 months (range 8-18 months). Results: Improvement occurred in all patients and was sustained in all cases throughout the follow-up period. The total complication rate was $5.26 \%(5 / 95)$. The main complications included depigmentation $(2.11 \%, 2 / 95)$, areolar ulcer $(2.11 \%, 2 / 95)$, and wire dislocation $(1.05 \%, 1 / 95)$. Conclusion: The nipple retractor is a simple tool with which severely inverted nipples can be successfully corrected with a low complication rate. Close follow-up and careful postoperative care are important to avoid complications.

\section{Introduction}

Inverted nipples are one of the main reasons of self-consciousness in women. Various methods have been published to correct inverted nipples, most of which include resection of the ducts and the surrounding fibrous tissue [1-3]. Such

\author{
Schlüsselwörter \\ Schlupfwarze · Operation · Mamillenretraktor
}

\section{Zusammenfassung}

Hintergrund: Schlupfwarzen sind ein häufiges Problem und oft schwierig zu korrigieren. Verschiedene korrektive Methoden sind berichtet worden, von denen die meisten zu einem Verlust des Stillvermögens führen. Material und Methoden: Wir haben einen einfachen Mamillenretraktor zur Korrektur von Schlupfwarzen entworfen. Bei insgesamt 53 Patientinnen mit 95 Schlupfwarzen wurde eine Operation durchgeführt, bei der die Brustwarze in die normale Position gezogen und anschließend mit dem Mamillenretraktor und Drähten fixiert wurde. Der Eingriff wurde unter Lokalanästhesie durchgeführt. Der Mamillenretraktor musste 6 Monate lang getragen werden. Das postoperative Follow-Up erfolgte an Tag 1, Tag 7, nach 1/3/6 Monaten und anschließend jährlich. Die Drähte wurden nach Bedarf adjustiert. Das mittlere Follow-Up war 11,9 Monate (Spanne 8-18 Monate). Ergebnisse: Bei allen Patientinnen waren Verbesserungen zu verzeichnen, die während der Follow-UpPeriode bestehen blieben. Die Gesamtkomplikationsrate war 5,26\% (5/95). Die Haupkomplikationen waren Depigmentation $(2,11 \%, 2 / 95)$, areoläre Ulzer $(2,11 \%, 2 / 95)$ sowie Drahtdislokation (1,05\%, 1/95). Schlussfolgerung: Der Mamillenretraktor ist ein einfaches Instrument, mit dem schwergradige Schlupfwarzen erfolgreich korrigiert werden können. Die Komplikationsrate ist niedrig. Ein gründliches Follow-Up und eine gewissenhafte postoperative Versorgung sind zur Vermeidung von Komplikationen wichtig.

methods may achieve good aesthetic result but often coincide with loss of breastfeeding function and nipple sensitivity. In order to avoid these complications, we have designed a simple nipple retractor to correct severely inverted nipples based on the theory of Ilizarov [4].

\section{KARGER \\ Fax +497614520714 \\ Information@Karger.de}

www.karger.com

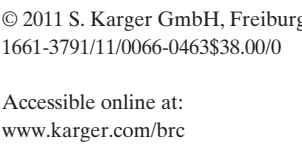

Ru Zhao, MD

Peking Union Medical College Hospital

Department of Plastic and Reconstructive Surgery

Beijing, China 100032

Tel. +86 1088068-974, Fax -836

pumclongxiao@gmail.com 


\section{Material and Methods}

To make the nipple retractor, a 10-ml syringe (or 5-ml syringe for patients with small nipples) is used, from which the plunger is removed. The syringe is cut with a sharp blade to retain $1 \mathrm{~cm}$ from the nozzle end. Then 4 symmetrical holes (fig. 1) are made at the bottom of the remaining part. The inverted nipple is retracted out with hanging threads and towel clamps under local anesthesia (fig. 2). A needle is passed through the base of the nipple and a stainless wire inserted to fixate the nipple with the retractor (fig. 3). Sufficient blood supply to the nipple must be ensured while tightening the wire. The skin is covered with Vaseline gauze and antibiotic ointment. Wire tension is adjusted every 4 weeks. The nipple retractor is removed after 6 months.

\section{Results}

From May 2003 to August 2010, the nipple retractor was used to correct 95 nipples in 53 patients. According to the criteria of Han and Hong [5], the 95 nipples were classified as grade II and grade III. The average age of the patients was 25.6 years (range 20-31 years). The total complication rate was $5.25 \%$, and none of the patients suffered infection, hematoma, permanent paresthesia, or nipple necrosis (table 1, figs. 4-5). The average follow-up time was 11.9 months (range 8-18 months), and no recurrences were observed (fig. 7). The nipple height had decreased by $4.7 \mathrm{~mm}$ on average (range $3-7 \mathrm{~mm}$ ) at 6 months post operation.

\section{Discussion}

An ideal method of correcting inverted nipples should meet the following requirements: i) regain normal shape; ii) keep visible scars at a minimum; iii) maintain normal sensation; iv) maintain an intact ductal system; v) low recurrence rate; and vi) easy to perform technique. Current surgical methods for grade III inverted nipples usually require division of the lactiferous ducts. Consequently, obstructive lactation is likely to occur postoperatively, and sometimes nipple-areola sensory loss might also appear. The nipple retractor technique was able to preserve breastfeeding function by keeping the ductal system intact, and no sensory loss was observed after the operation. Thus, with this method, the main complications of other techniques can be avoided.

Most procedures to correct inverted nipples focus on sufficient release of fibrous tissue or filling the space beneath the nipple $[6,7]$. In contrast, our technique is based on the theory of Ilizarov [4] that continuous stress could stimulate and maintain tissue regeneration. Furthermore, overcorrection of the inverted nipple could help prevent recurrences, which is the main reason for the stable and satisfying aesthetic results achieved with the nipple retractor technique.

The procedure is relatively simple and quick to perform compared with other techniques which usually require multiple flaps. Possible complications include areolar erosion or insufficient blood supply due to overretraction. Thus followup in the first $24-48 \mathrm{~h}$ post operation is suggested to observe the blood supply to the nipple and adjust the wires. According to our experience, 6 months of retraction is recommended. Patients need to be seen again at 1 month and 3 months post operation in order to further adjust the wires.

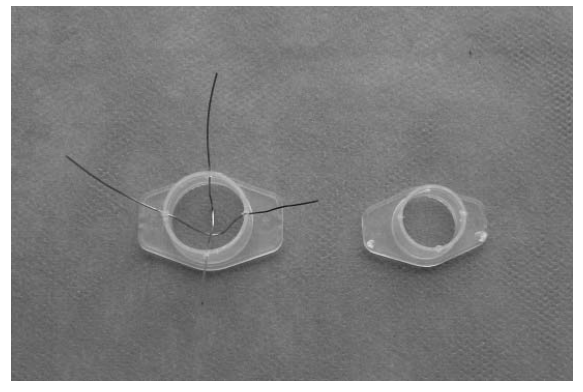

Fig. 1. A $10 \mathrm{ml}$ or $5 \mathrm{ml}$ syringe is used to make the nipple retractor.

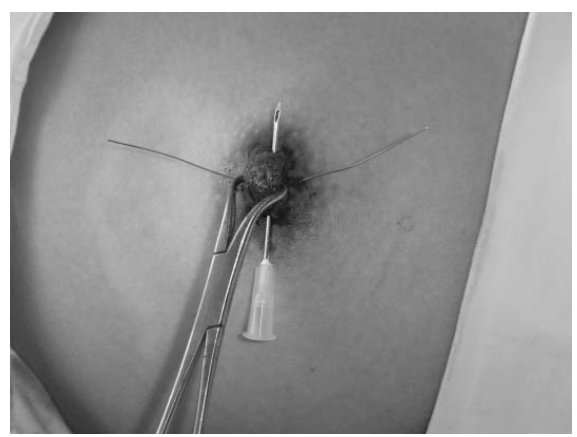

Fig. 2. Piercing procedure for inverted nipple using a crossed wire.

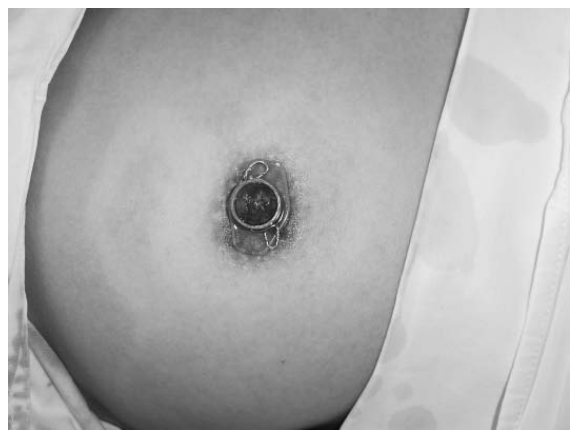

Fig. 3. Fixation of the nipple retractor using the wire.

Table 1. Complication rates among 95 nipple correction procedures

\begin{tabular}{|c|c|c|c|c|c|c|}
\hline & \multicolumn{6}{|l|}{ Cases, n (\%) } \\
\hline & depigmentation & areolar ulcer & wire dislocation & nipple necrosis & hypertrophic scar & paresthesia \\
\hline Grade II (20/95) & 0 & 0 & 0 & 0 & 0 & 0 \\
\hline Grade III (75/95) & 2 & 2 & 1 & 0 & 0 & 0 \\
\hline Total & $2(2.11 \%)$ & $2(2.11 \%)$ & $1(1.05 \%)$ & 0 & 0 & 0 \\
\hline
\end{tabular}




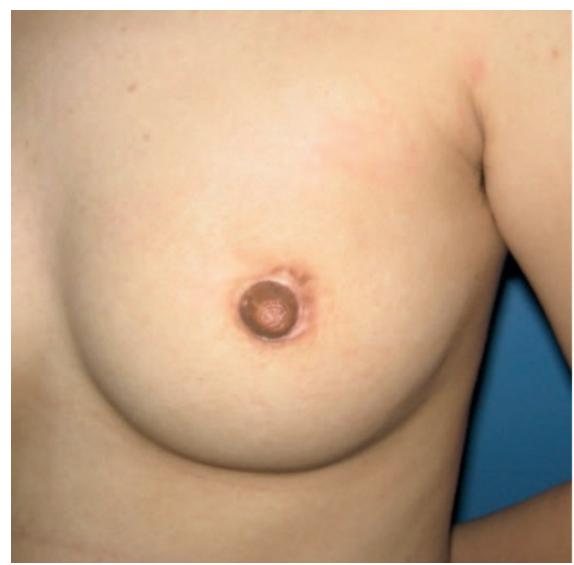

Fig. 4. Areolar depigmentation.

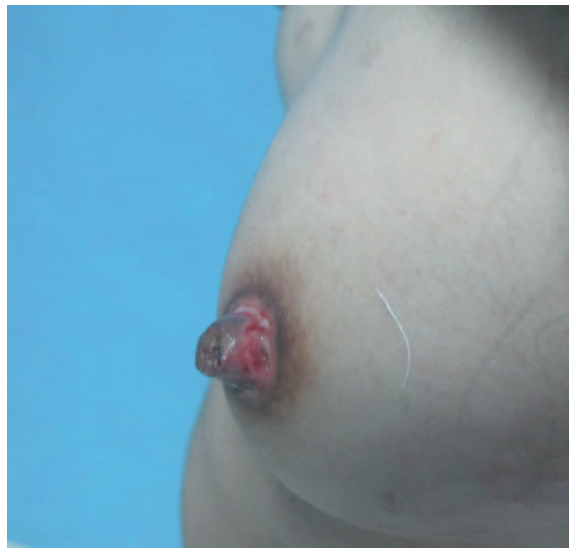

Fig. 5. Areolar ulcer.

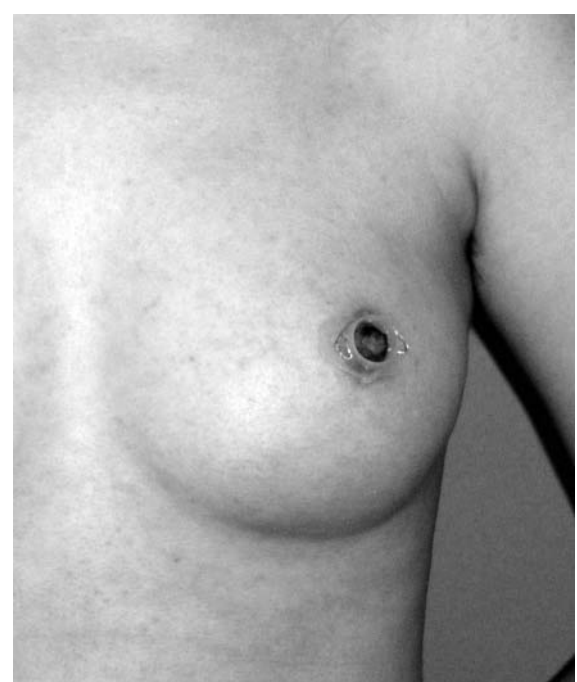

Fig. 6. Wire dislocation.

\section{Conclusion}

The nipple retractor is a simple technique which can be easily performed under local anesthesia. Satisfying aesthetic results can be achieved without destroying nipple function or sensation. Close follow-up and careful postoperative care are important to avoid complications. Additional studies with a larger number of patients and longer follow-up are necessary to confirm these results.

\section{Disclosure Statement}

The authors have no conflicts of interest to disclose.

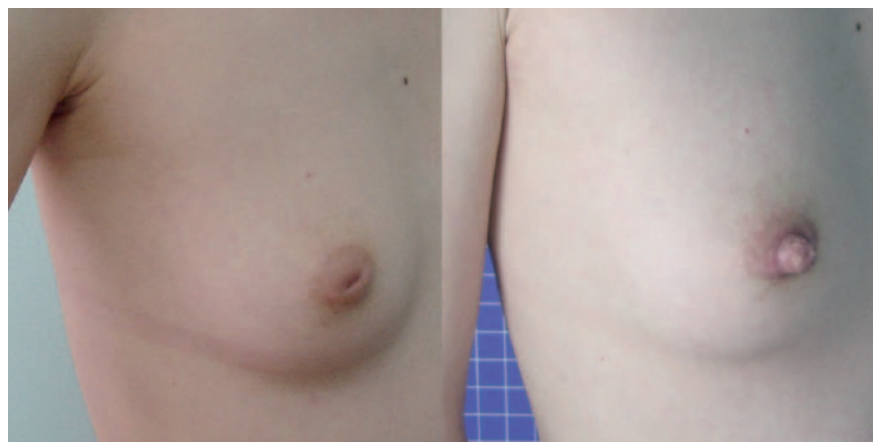

Fig. 7. 24-year-old female patient: preoperative view (left) and postoperative result (right) after nipple retractor had been removed for 6 months (1 year post operation).

\section{References}

1 Burm JS, Kim YW: Correction of inverted nipples by strong suspension with areolar-based dermal flaps. Plast Reconstr Surg 2007;120:1483-1486.

2 Min KH, Park SS, Heo CY: Scar-free technique for inverted-nipple correction. Aesth Plast Surg 2010;34:116-119.

$\checkmark 3$ Crestinu JM: The correction of inverted nipples without scars: 17 years' experience, 452 operations. Aesth Plast Surg 2000;24:52-57.
4 Ilizarov GA: The tension-stress effect on the genesis and growth of tissue: the influence of stability of fixation and soft-tissue preservation. Clin Orthop 1989;239:264.

5 Han S, Hong YG: The inverted nipple: its grading and surgical correction. Plast Reconstr Surg 1999;104:389.
6 Hyakusoku H, Chin T: Usefulness of the nipplesuspension piercing device after correction of inverted nipple. Aesth Plast Surg 2006;30:396-398.

7 Peeters G, Decloedt J, Nagels H, Cambier B: Treatment of the severe or recurrent inverted nipple by interposition of a resorbable polydioxanone sheet. J Plast Reconstr Aesthet Surg 2010; 63:e175-e176. 